\title{
Grade IV blunt hepatic injury treated conservatively and successfully in a non-trauma centre: a case report
}

\author{
Sebastian Berg ${ }^{1 *}$, Jean-Charles de Schoutheete ${ }^{1}$, Davide Di Mauro ${ }^{2}$, Matteo Gregori², \\ Edoardo Ricciardi², Antonio Manzelli²
}

\begin{abstract}
${ }^{1}$ Department of Surgery. Queen Astrid Military Hospital, Bruynstraat 1, 1120 Brussels, Belgium
${ }^{2}$ Department of Upper Gastro-Intestinal Surgery. Royal Devon and Exeter Hospital, Barrack Road, Exeter, Devon, EX2 5DW, United Kingdom
\end{abstract}

Received: 29 April 2021

Revised: 05 June 2021

Accepted: 07 June 2021

\section{*Correspondence:}

Dr. Sebastian Berg,

E-mail: sebastianberg87@gmail.com

Copyright: ( ) the author(s), publisher and licensee Medip Academy. This is an open-access article distributed under the terms of the Creative Commons Attribution Non-Commercial License, which permits unrestricted non-commercial use, distribution, and reproduction in any medium, provided the original work is properly cited.

\begin{abstract}
Management of blunt hepatic injury changed over the past three decades as a non-operative treatment is nowadays advocated by most in haemodynamically stable patients. We present the case of a young female patient with a highgrade blunt liver injury successfully treated in a non-trauma centre. She developed several complications secondary to the injury like a delayed bleeding, two different bilomas and a reactive pleural effusion requiring surgical expertise, interventional radiology, upper gastro-intestinal endoscopy and intensive care facilities. In the literature, the mortality and the morbidity rates for grade IV liver injuries respectively reach $16 \%$ and $39 \%$. Because of potential delayed symptoms or signs and high complication rate, we think it should be appropriate to manage such a complex patient in a centre where at least above-mentioned specialities are available. Otherwise, a referral to a trauma centre should be a better option.
\end{abstract}

Keywords: Trauma, Blunt hepatic injury, Nonoperative management, Interventional radiology, Endoscopy

\section{INTRODUCTION}

Liver injuries can be categorized as being due to blunt or penetrating mechanisms of trauma, with violent behaviour and road traffic accidents accounting for the majority of cases in the UK and the USA. ${ }^{1}$ Over the last three decades a paradigm shift took place from exploratory laparotomies to non-operative management being considered the standard care for haemodynamically stable patients. ${ }^{2-6}$

Despite conservative treatment, up to $14 \%$ of patients with high- grade injuries develop complications such as bile leak, delayed bleeding, hepatic or perihepatic abscesses, cholecystitis, or even liver failure that need prompt recognition and treatment. ${ }^{7-9}$
We present a complex case of grade IV blunt hepatic injury treated non-operatively in a non-trauma centre. ${ }^{10,11}$ This is a unique case as it demonstrates that cases of high level of complexity can also be successfully managed conservatively with a good outcome. We think that it would definitely support the existing literature in formulating guidelines of management of complex abdominal trauma.

\section{CASE REPORT}

A 30-years-old female patient was admitted to the Emergency Department with pain in the right chest and right shoulder after slipping and falling from her bicycle at $20 \mathrm{~km} / \mathrm{h}$. Upon admission her vital signs were all within the normal range and the ABCDE primary survey 
was unremarkable apart from minor skin abrasions on her right hand. Besides of an arthroscopic reconstruction of ligaments of a knee she had a blank past medical history. Plane radiography of her chest and of her right shoulder were unremarkable as well as the baseline biochemistry tests. The abdomen on examination was soft and nontender. She was discharged pain free home after 4 hours observation period.

Three days later the patient came back to the emergency department with a 12 hours history of increasing abdominal pain and passing dark brown coloured urine. On abdominal examination she was tachycardic at $110 /$ minute. The abdomen on examination was soft with no signs of peritonism but tender in right upper quadrant. Blood results showed raised bilirubin ( $34 \mathrm{umol} / \mathrm{L}$ ) and alanine aminotransferase (615 IU/L), while haemoglobin and white cell count were within the normal range. A FAST scan done in emergency department showed some free fluid around liver and the pelvis. An urgent computed tomography (CT) scan of the abdomen and pelvis was prompted, showing a grade IV liver injury with a laceration of segments V, VII and VIII and a moderate amount of perihepatic free fluid (Figure 1). The patient received intravenous crystalloids and painkillers and, since she was haemodynamically stable, a nonoperative management was attempted. In order to achieve optimal pain control, a thoracic epidural catheter was inserted.

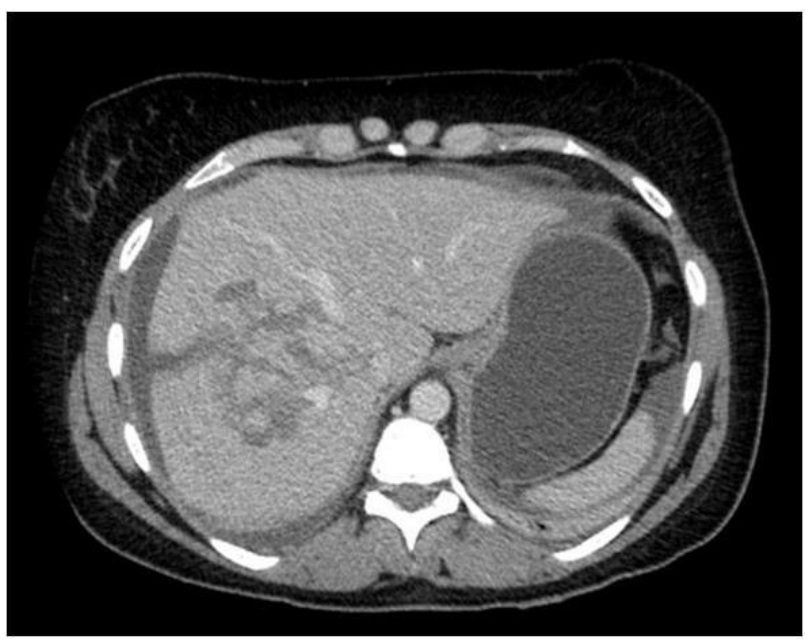

Figure 1: CT-scan on PID 3 (Laceration in segments V, VII and VIII with moderate intra-abdominal free fluid).

On post injury day (PID) 7 a follow-up CT scan of the abdomen showed a moderately increased amount of perihepatic fluid (Figure 2) which did not require treatment. As the patient suddenly dropped her serum haemoglobin from 9.2 to $7.3 \mathrm{~g} / \mathrm{dl}$ a new CT scan of the abdomen was performed on PID 13 (Figure 3). It showed two organized collections: one of $14 \times 9 \times 8$ centimetres in the subhepatic area, exerting pressure on the liver capsule at level of segments $\mathrm{V}$ and VI and another one of
$13 \times 12 \times 7 \mathrm{~cm}$ in the subphrenic area, exerting some compression on segments VII and VIII (Figure 7), both in keeping with a biloma. The larger one was successfully drained under ultrasound guidance on the day after but the LFT's did not improve so the second collection required an ultrasound guided drainage as well on PID 21 after a new CT scan still showed a collection (Figure 4).

After both drains were removed the patient experienced increasing discomfort in the upper abdomen. A new ultrasound of the abdomen showed persistence of the subphrenic collection and required a re-insertion of an ultrasound-guided drain on PID 27. The patient was sent home on PID 31 with the abdominal drain inside, still producing about 200 millilitres bile a day.

Unfortunately, the patient was readmitted to hospital on PID 41 with worsening abdominal pain and deranged LFT's. A new ultrasound scan confirmed the presence of a subphrenic collection; hence the patient underwent an endoscopic retrograde cholangio-pancreatography (ERCP) with sphincterotomy and stenting of the common bile duct. Obvious bile leak was excluded with cholangiography.

By PID 43 the collection was much smaller on the control CT-scan (Figure 5), but a large right pleural effusion was demonstrated and required an ultrasound-guided drainage. The abdominal and the chest drains were removed on PID 47 and 48, respectively, and the patient was discharged on PID 50. Nine months after the trauma, a follow-up CT scan showed only scarring within the liver (Figure 6). The biliary stent was removed one year after trauma and the ultrasound scan at this time showed unremarkable appearances of the liver and the common bile duct.

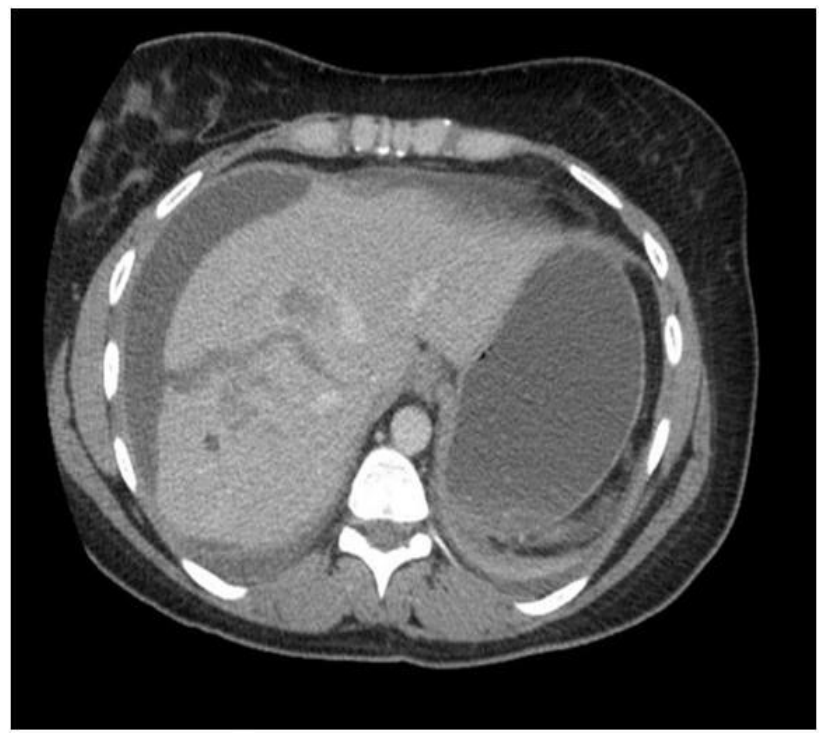

Figure 2: CT-scan on PID 7 (Some resolution of the liver lacerations but increasing intra-abdominal free fluid). 


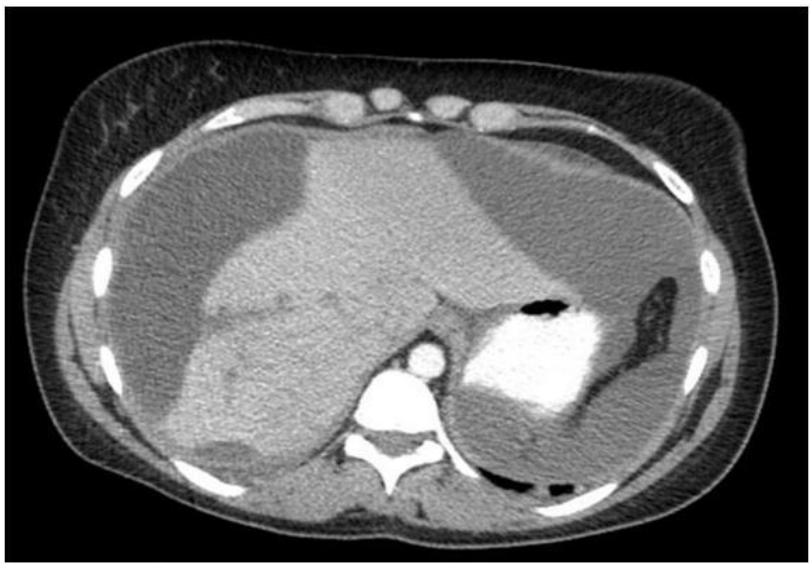

Figure 3: CT-scan on PID 13 (Increasing intraabdominal free fluid compressing the liver parenchyma and exerting some sort of mechanical haemostasis. Densities of the right and left sided fluids are not the same, suggesting a bile leak on the right side).

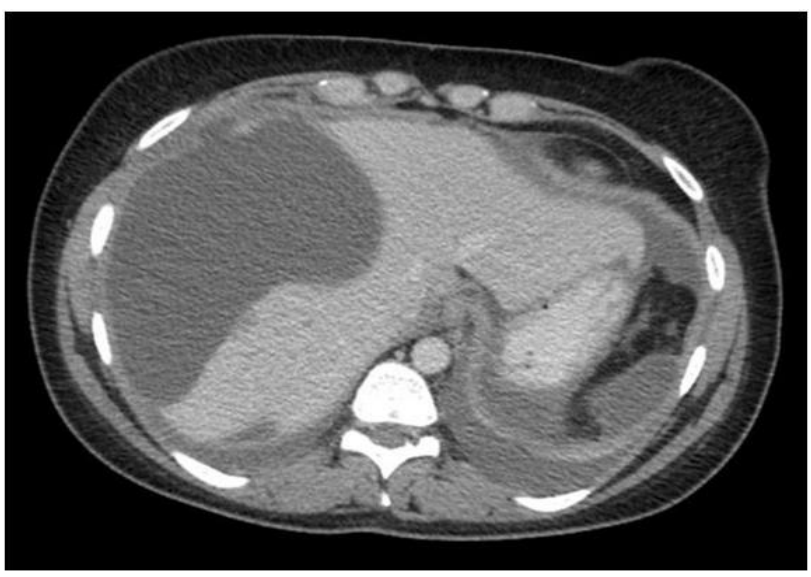

Figure 4: CT-scan on PID 21 (Lacerations have almost disappeared due to compression. Defined bile leak requiring drainage).

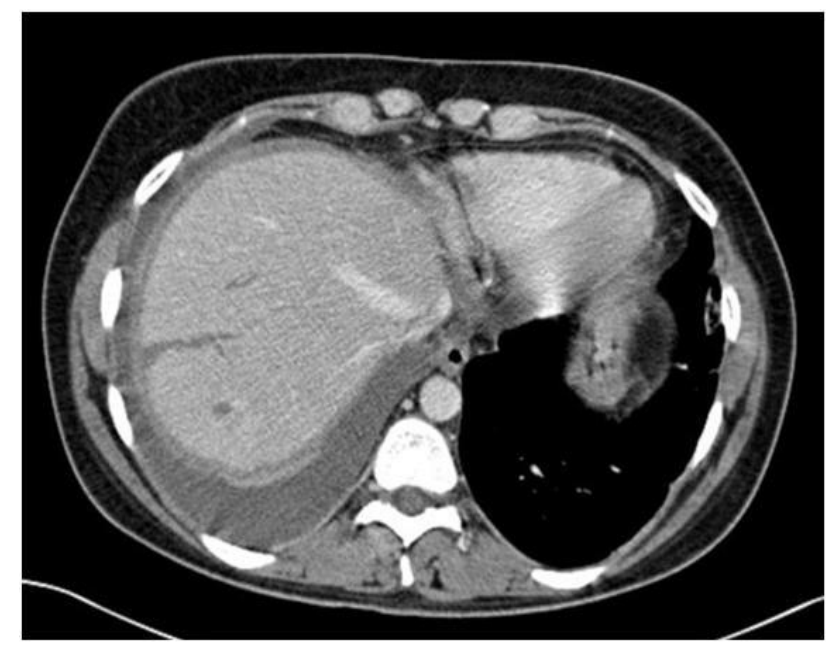

Figure 5: CT-scan on PID 43 (right basal pleural effusion requiring drainage).

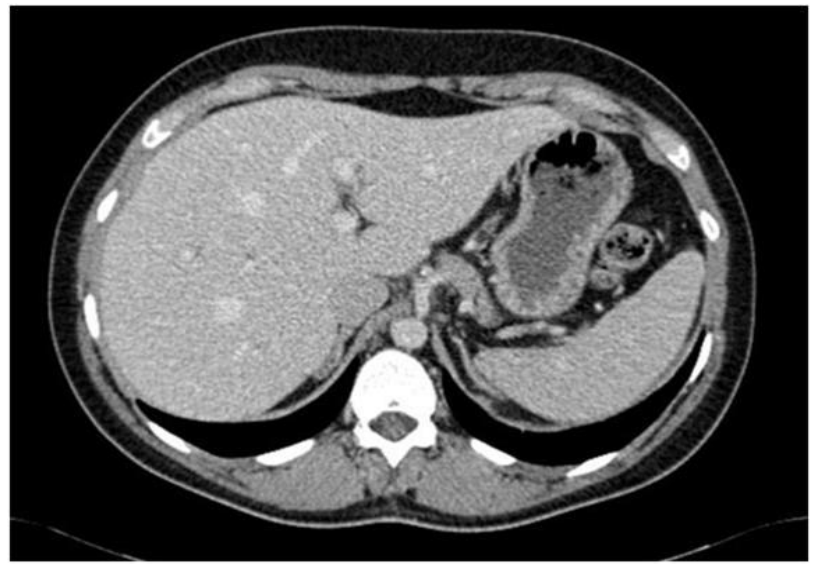

Figure 6: CT-scan 9 months after trauma (complete healing of the liver lacerations. Only a peripheral scar can still be seen).

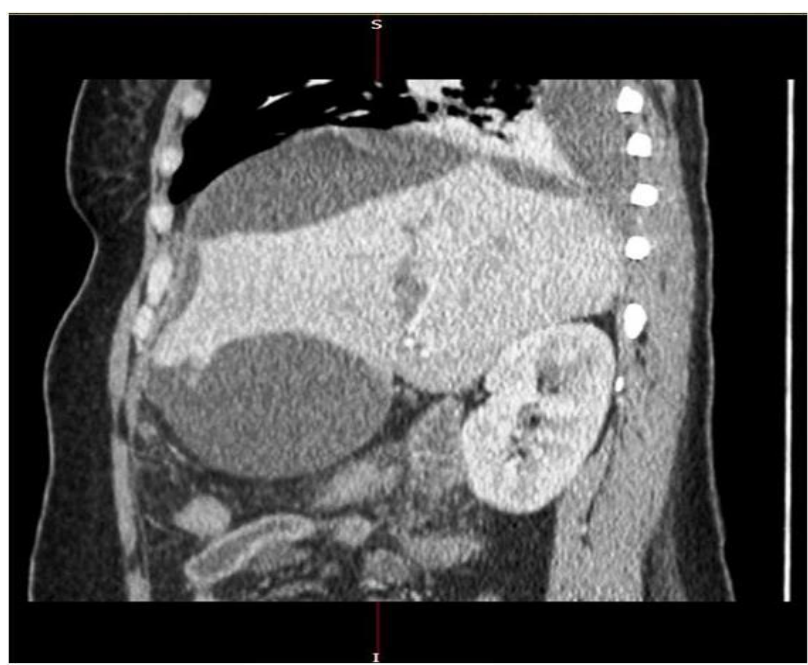

Figure 7: CT-scan on PID 13 (sagittal reconstruction) showing two bilomas. The subhepatic one was drained on PID 13 and the subphrenic one was drained one week later.

\section{DISCUSSION}

Non operative management is considered the treatment of choice for haemodynamically stable patients with blunt as well as perforating liver injury in the absence of other internal injuries requiring surgery. ${ }^{3,5,6}$ The availability of continuous clinical monitoring, serial haemoglobin checks, CT scanning, angiography, around the clock availability of an operation theatre together with trained surgeons, blood and blood products have been described as a set of minimum requirements to safely attempt a conservative approach of treatment. Clear guidelines for follow up are still needed but repeat CT seems to only be necessary if clinical examination or blood tests are suspicious for complications. ${ }^{7,8,11}$

The shift towards a non-operative management of highgrade liver injuries over the past three decades has resulted in a lower mortality rate, but there is still a 
significant percentage of complications which is partly a natural consequence of the liver injury. ${ }^{7,8,18}$ In the literature, the mortality rate for grade IV liver injuries varies between $0 \%$ and $16 \%{ }^{19,20}$ and it seems damage control resuscitation measures can improve the success rate. $^{20}$ Morbidity for a grade IV liver injury varies between $0 \%$ and $39 \% .^{21-23}$ Biliary complications have been reported in 2.8 to $30 \%$ of patients with blunt hepatic trauma and it may present in a delayed fashion in patients with grade IV injuries. ${ }^{3,13,22,25,26}$ In the literature a delayed bleeding ( $>24$ hours) in case of a grade IV injury after blunt liver trauma is well described and occurs in up to $45 \%$ of patients, requiring transfusion in $66.7 \%$ cases with an average of $2.26 \pm 1.57$ units of packed red blood cells. ${ }^{21}$ Most traumatic bilomas regress spontaneously. If they become symptomatic, enlarge or get infected, percutaneous drainage has been described as an efficient treatment, but in our cases, it was not effective and the patient required an ERCP with sphincterotomy and biliary stenting, the latter providing with healing rates of $90 \%$ to $100 \%$. Laparotomy is the usual treatment for bile peritonitis, but a combination of laparoscopic drainage and endoscopic bile duct stenting represents a valid alternative. ${ }^{29}$

In accordance with current guidelines our patient has been treated with non-operative measures. ${ }^{11}$ The bilomas that she developed as complications to her injury were treated primarily with percutaneous drainage and secondarily with ERCP and bile duct stenting, both were viable treatment options according to the literature. Delayed bleeding is another complication commonly seen in high grade injuries, these should be primary treated with angioembolisation., ${ }^{7,8}$ Pseudoaneurysm formation especially of the common hepatic artery is relatively rare but with a mortality rate of up $18 \%$, asymptomatic pseudoaneurysm should be treated as soon as possible with angioembolisation because of the high risk of rupture and associated high morbidity. ${ }^{7,8}$ Abscesses are relatively uncommon after non operative treatment with a prevalence of $0.7-7 \%$ and can safely be drained with percutaneous CT or ultrasound-guidance. ${ }^{7,8}$

\section{CONCLUSION}

As conclusion, the case we present here is that of a patient with a high-grade blunt liver injury, who was successfully managed in a non-trauma centre. Although she did not sustain massive bleeding and did not require operative treatment, she developed bilomas which are well described complications in the literature, that required prompt treatment. In a modern trauma system, all major trauma patients should be directly referred to the nearest trauma centre where patients have prompt access to the needed facilities and expertise. In the event of a patient with high grade liver injury being admitted in a non-trauma centre, surgical expertise, interventional radiology, upper gastro-intestinal endoscopy and intensive care facilities are mandatory requirements to provide a safe and effective treatment. If one of the above is not promptly available, we feel such a complex patient, after primary resuscitation, should be referred to the nearest trauma centre.

\section{Funding: No funding sources \\ Conflict of interest: None declared \\ Ethical approval: Not required}

\section{REFERENCES}

1. Parks RW, Chrysos E, Diamond T. Management of liver trauma. Br J Surg. 1999;86:1121-35.

2. Morrison JJ, Bramley KE, Rizzo AG. Liver trauma-operative management. J R Army Med Corps. 2011;157(2):136-44.

3. Boese CK, Hackl M, Müller LP, Ruchholtz S, Frink $\mathrm{M}$, Lechler P. Nonoperative management of blunt hepatic trauma: a systematic review. J Trauma Acute Care Surg. 2015;79(4):654-60.

4. Fodor M, Primavesi F, Morell-Hofert D, Haselbacher M, Braunwarth E, Cardini B et al. Non-operative management of blunt hepatic and splenic injuriespractical aspects and value of radiological scoring systems. Eur Surg. 2018;50(6):285-98.

5. Parks NA, Davis JW, Forman D, Lemaster D. Observation for nonoperative management of blunt liver injuries: how long is long enough? J Trauma. 2011;70(3):626-9.

6. Hommes M, Navsaria PH, Schipper IB, Krige JEJ, Kahn D, Nicol AJ. Management of blunt liver trauma in $134 \quad$ severely injured patients. Injury. 2015;46(5):837-42.

7. Kozar RA, Moore FA, Moore EE, West M, Cocanour CS, Davis $\mathrm{J}$ et al. Western Trauma Association critical decisions in trauma: nonoperative management of adult blunt hepatic trauma. J Trauma. 2009;67(6):1144-8.

8. Fabian TC, Bee TK. Liver and Biliary Tract. In: Feliciano D, Mattox K, Moore E, editors. Trauma $6^{\text {th }}$ ed. McGraw-Hill Medical. 2008;851-70.

9. Bala M. Complications of high-grade liver injuries: management and outcome with focus on bile leaks. Scandinavian J Trauma, Resuscitation and Emergency Med. 2012;20:20.

10. Moore EE, Shackford SR, Pachter HL, McAninch JW, Browner BD, Champion HR et al. Organ injury scaling: spleen, liver, and kidney. J Trauma. 1989;29:1664-6.

11. Moore EE, Cogbill TH, Jurkovich GJ, Shackford SR, Malangoni MA, Champion HR. Organ injury scaling: spleen and liver. J Trauma. 1995;38:323-4.

12. Stassen NA, Bhullar I, Cheng JD, Crandall ML, Friese RS, Guillamondegui OD et al. Eastern Association for the Surgery of Trauma. Nonoperative management of blunt hepatic injury: an Eastern Association for the Surgery of Trauma practice management guideline. J Trauma Acute Care Surg. 2012;73(5-4):S288-93.

13. Velmahos GC, Toutouzas KG, Radin R, Chan L, Demetriades D. Nonoperative treatment of blunt 
injury to solid abdominal organs: a prospective study. Arch Surg. 2003;138(8):844-51.

14. Yanar H, Ertekin C, Taviloglu K, Kabay B, Bakkaloglu H, Guloglu R. Nonoperative treatment of multiple intra-abdominal solid organ injury after blunts abdominal trauma. J Trauma. 2008;64(4):943-8.

15. Fang JF, Wong YC, Lin BC, Hsu YP, Chen MF. The $\mathrm{CT}$ risk factors for the need of operative treatment in initially hemodynamically stable patients after blunt hepatic trauma. J Trauma. 2006;61:3.

16. Fang JF, Chen RJ, Wong YC, Lin BC, Hsu YB, Kao $\mathrm{JL}$ et al. Pooling of contrast material on computed tomography mandates aggressive management of blunt hepatic injury. Am J Surg. 1998;176(4):315-9.

17. Piper GL, Peitzman AB. Current management of hepatic trauma. Surg Clin North Am. 2010;90(4):775-85.

18. Velamhaos GC, Konstantinos T, Radan R, Chan L, Rhee P, Tillou A et al. High success with nonoperativemanagement of blunt hepatic trauma. Arch Surg. 2003;138:475-81.

19. Coimbra R, Hoyt DB, Engelhart S, Fortlage D. Nonoperative management reduces the overall mortality of grades 3 and 4 blunt liver injuries. Int Surg 2006;91(5):251-7.

20. Shrestha B, Holcomb JB, Camp EA, Del Junco DJ, Cotton BA, Albarado A et al. Damage-control resuscitation increases successful nonoperative management rates and survival after severe blunt liver injury. J Trauma Acute Care Surg. 2015;78:336-41.

21. Zago TM, Pereira BMT, Calderan TRA, Godinho M, Nascimento B, Fraga GP. Nonoperative management for patients with grade IV blunt hepatic trauma. World J Emergency Surg. 2012;7(1):S8.

22. Kozar RA, Moore JB, Niles SE. Complications of non-operative management of high-grade blunt hepatic injuries. J Trauma. 2005;59:1066-071.

23. Duane TM, Como JJ, Bochicchio GV, Scalea TM. Re-evaluating the management and outcomes of severe blunt liver injury. J Trauma. 2004;57(3):494500.

24. Schnüriger B, Inderbitzin D, Schafer M, Kickuth R, Exadaktylos

A, Candinas

D.
Concomitant injuries are an important determinant of outcome of blunt hepatic trauma. $\mathrm{Br} \mathrm{J}$ Surg. 2009;96:104-10.

25. Carrillo EH, Spain DA, Wohltmann CD, Schmieg RE, Boaz PW, Miller FB et al. Interventional techniques are useful adjuncts in nonoperative management of hepatic injuries. $\mathrm{J}$ Trauma. 1999;46:619-22.

26. Kozar RA, Moore FA, Cothren CC. Risk factors for hepatic morbidity following nonoperative management. Arch Surg. 2006;141:451-8.

27. Singh V, Narasimhan KL, Verma GR, Singh G. Endoscopic management of traumatic hepatobiliary injuries. J Gastroenterol Hepatol. 2007;22:1205-9.

28. Lubezky N, Konikoff FM, Rosin D, Carmon E, Kluger Y, Ben-Haim M. Endoscopic sphincterotomy and temporary internal stenting for bile leaks following complex hepatic trauma. $\mathrm{Br} \mathrm{J}$ Surg. 2006;93:78-81.

29. Carrillo EH, Spain DA, Wohltmann CD, Schmieg RE, Boaz PW, Miller FB et al. Interventional techniques are useful adjuncts in nonoperative management of hepatic injuries. J Trauma. 1999;46(4):619-22.

30. De Backer A, Fierens H, De Schepper A, Pelckmans P, Jorens PG, Vaneerdeweg W. Diagnosis and nonsurgical management of bile leak complicated by biloma after blunt liver injury: report of two cases. Eur Radiol. 1998;8(9):1619-22.

31. D'Amours SK, Simons RK, Scudamore CH, Nagy AG, Brown DR. Major intrahepatic bile duct injuries detected after laparotomy: selective nonoperative management. J Trauma. 2001;50(3):480-84.

32. Nathan M, Gates J, Ferzoco SJ. Hepatic duct confluence injury in blunt abdominal trauma: case report and synopsis on management. Surg Laparosc Endosc Percutan Tech. 2003;13(5):350-2.

Cite this article as: Berg S, De Schoutheete JC, Mauro DD, Gregori M, Ricciardi E, Manzelli A. Grade IV blunt hepatic injury treated conservatively and successfully in a non-trauma centre: a case report. Int Surg J 2021;8:2161-5. 